\title{
Ridolfia segetum Moris (false fennel) response to different rates of application of Metsulfuron Methyl
}

\author{
Hajjaj B*, El Oualkadi A*
}

*Regional Agricultural Research Center of Tangier, Morocco
Corresponding author. E-mail: h_badr15@yahoo.fr

\begin{abstract}
High infestations of Ridofia segetum can cause wheat crops yield reduction. The aim of this study is to investigate the effect of Metsulfuron Methyl on R. segetum infestation in a soft wheat crop. The experimental design was Randomized Complete Block Design (RCBD) with three replications. Each block contained 4 elementary plots, 3 plots of which were treated with three rates of application of Metsulfuron Methyl and one untreated control plot. Trial were conducted in Ouazzane region of Morocco in January 2018. Treatments were carried out with a knapsack sprayer with the nozzle delivering a 3 bar jet. A quadrant of $1 \mathrm{~m} x 1 \mathrm{~m}$ was used to calculate percentage of $R$. segetum density reduction and biomass reduction. $R$. segetum dry biomass were determined using an oven at $75^{\circ} \mathrm{C}$ for 48 hours. Then, weighed with a precision balance. Results showed that treatments with Metsulfuron Metsulfuron Methyl at $6 \mathrm{~g} / \mathrm{ha}$ and $9 \mathrm{~g} / \mathrm{ha}$ gave the best control of $R$. segetum infestations recording respectively $92.5 \%$ and $94.6 \%$ of $R$. segetum density reduction and $92.7 \%$ and $94.6 \%$ of $R$. segetum dry biomass reduction. Metsulfuron Methyl at $3 \mathrm{~g} / \mathrm{ha}$ recorded the lowest efficacies 61.9 and $48.8 \%$ respectively on $R$. segetum density reduction, and $R$. segetum dry biomass reduction.
\end{abstract}

Keywords-Ridolfia segetum, Metsulfuron Methyl, wheat, density, biomass.

\section{INTRODUCTION}

Weeds are a serious problem in cereal crops in Morocco and severely affect production yields (Zimadahl \& El Brahli, 1992; Boutahar, 1994; Taleb, 1996; Bouhache, 2007; Bouhache, 2017). Ridolfia segetum Moris (false fennel) belongs to Apiaceae botanical Family. It's an annual plant, hairless, fennel-smelling. Stem upright, usually $30 \mathrm{~cm}$ to $1 \mathrm{~m}$ high. Leaves divided into very thin segments (Tanji, 2005). Top leaves reduced. Inflorescence in umbels of 10 to 40 rays of 3 to $8 \mathrm{~cm}$. Corolla with 5 yellow petals fringed. Ovoid seeds, 2 to $3 \mathrm{~mm}$ long and 0.5 to $1 \mathrm{~mm}$ wide, hairless, smooth, brown, 5 thin ribs (Tanji, 2005). Plant present in different region of Morocco usually on clay soils. Plant eaten by livestock especially before flowering (Tanji, 2005). Metsulfuron Methyl is an herbicide that belongs to the Sulfonylureas family. A small amount of active ingredient is used to kill weeds in cereal crops. It is an herbicide used to exterminate many annual or perennial broadleaf weeds (Ezzahiri \& al., 2017). It is a systemic herbicide absorbed by root and leaves to inhibit cell division in the shoots and roots of the plant. It can be sprayed on leaves or soil and its action has some remanence. Ridolfia segetum become a serious problem in cereal fields in Ouazzan region of Morocco by reducing yields and making harvesting difficult. The aim of this study is to compare the effect of three doses of Metsulfuron Methyl on the Ridolfia segetum infestation in in a soft wheat crop in the Ouazzan region of Morocco.

\section{MATERIAL AND METHODS}

A weeding trial was conducted in Ouazzane region of Morocco during 2017-2018 growing season. The experimental design was Randomized Complete Block Design (RCBD) with three replications. The distance between the blocks was 2 meters and the distance between plots was 1 meter. Each block contained 4 elementary plots, 3 plots of which were treated with the postemergence herbicides tested (Table 1) and one untreated control plot. The size of the elementary plots was $2 \mathrm{~m} \times 5 \mathrm{~m}$ $\left(10 \mathrm{~m}^{2}\right)$. Treatments was carried out on January 5, 2018 with a Knapsack herbicide sprayer with nozzle delivering a 3 bar jet. The spray volume per hectare is 200L. Treatments consist on three rates of application of Metsulfuron Methyl (Table 1). Observations were at 60 days after application of herbicides. Observations concerned Percentage of $R$. segetum density reduction and biomass reduction. $R$. segetum density reduction percentage $=[R$. segetum density in control plots $-R$. segetum density in treated plots] $\mathrm{x} 100 /[R$. segetum density in control plots], Calculation of the density at the 
experimental level of the plot was made by a quadrant of $1 \mathrm{~m} \times 1 \mathrm{~m}$. $R$. segetum dry biomass reduction percentage $=$ $[R$. segetum dry biomass weight in control plots $-R$. segetum dry biomass weight in treated plots] $\mathrm{x} 100 /[R$. segetum dry biomass weight in control plots]. Calculation of dry $R$. segetum biomass were made by collecting $R$. segetum in each plot using a quadrant of $1 \mathrm{~m} \times 1 \mathrm{~m}$. Samples were dried in a drying oven at $75^{\circ} \mathrm{C}$ for 48 hours. Then, dry plant material in each plot were weighed with a precision balance. Statistical analyzes were performed with IBM SPSS Statistics, version 21.0 using the analysis of variance (ANOVA).The differences among treatment means was compared by Tukey's test at $P=0.05$.

Table 1: Applied herbicides in experimental site

\begin{tabular}{lll}
\hline $\begin{array}{l}\text { Herbicide } \\
\text { treatments }\end{array}$ & $\begin{array}{l}\text { Herbicide active } \\
\text { ingredient }\end{array}$ & $\begin{array}{l}\text { rate } \\
\text { application } \\
\text { (g/hectare) }\end{array}$ \\
\hline Treatment 1 & $\begin{array}{l}\text { Metsulfuron } \\
\text { Methyl }\end{array}$ & $3 \mathrm{~g} / \mathrm{ha}$ \\
\hline Treatment 2 & $\begin{array}{l}\text { Metsulfuron } \\
\text { Methyl }\end{array}$ & $6 \mathrm{~g} / \mathrm{ha}$ \\
\hline Treatment 3 & $\begin{array}{l}\text { Metsulfuron } \\
\text { Methyl }\end{array}$ & $9 \mathrm{~g} / \mathrm{ha}$ \\
\hline
\end{tabular}

\section{RESULTS AND DISCUSSION}

\section{Effect on $R$. segetum density reduction}

Statistical analysis revealed significant differences between treatments (Table 2). Results in Table 2 showed that the best $R$. segetum density reduction was obtained by Metsulfuron Methyl at $6 \mathrm{~g} / \mathrm{ha}$ and $9 \mathrm{~g} / \mathrm{ha}$ recording respectively $92.5 \%$ and $94.6 \%$ of $R$. segetum density reduction. Metsulfuron Methyl at $3 \mathrm{~g} / \mathrm{ha}$ showed medium efficacies that did not exceed $61.9 \%$ of $R$. segetum density reduction.

Table 2: Effect of treatments on $R$. segetum density reduction $(\%)$

\begin{tabular}{cc}
\hline Treatments & $\begin{array}{c}\text { R. segetum density } \\
\text { reduction }(\%)\end{array}$ \\
\hline $\begin{array}{c}\text { Metsulfuron Methyl } \\
\text { at } 3 \mathrm{~g} / \mathrm{ha}\end{array}$ & $61.9^{\mathrm{a}}$ \\
\hline $\begin{array}{c}\text { Metsulfuron Methyl } \\
\text { at } 6 \mathrm{~g} / \mathrm{ha}\end{array}$ & $92.5^{\mathrm{b}}$ \\
$\begin{array}{c}\text { Metsulfuron Methyl } \\
\text { at } 9 \mathrm{~g} / \mathrm{ha}\end{array}$ & $94.6^{\mathrm{b}}$ \\
\hline$P \alpha=0.05$ & $<0.001$ \\
\hline
\end{tabular}

Significant differences within the same column and means followed by the same letter do not differ at $P=0.05$ according to Tukey's test

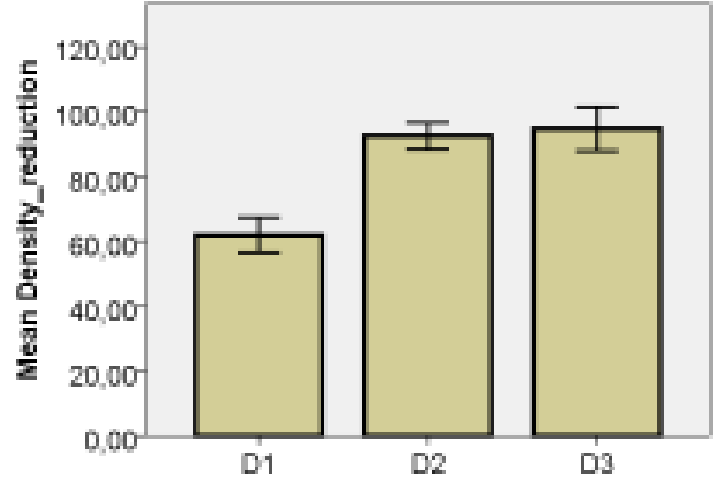

D1 : Metsulfuron Methyl at $6 \mathrm{~g} / \mathrm{ha}$; D2 : Metsulfuron Methyl at $6 \mathrm{~g} / \mathrm{ha}$; D3 : Metsulfuron Methyl at $9 \mathrm{~g} / \mathrm{ha}$

Error Bars: $95 \%$ CI

Fig.1: Effect of treatments on $R$. segetum density reduction $(\%)$

\section{Effect on $\boldsymbol{R}$. segetum dry biomass reduction}

Statistical analysis revealed significant differences between treatments (Table 3). Data in Table 3 indicate that the best $R$. segetum dry biomass reduction was achieved by Metsulfuron Methyl at $6 \mathrm{~g} / \mathrm{ha}$ and $9 \mathrm{~g} / \mathrm{ha}$ recording respectively $92.7 \%$ and $94.5 \%$ of $R$. segetum dry biomass reduction. Concerning the effect of Metsulfuron Methyl at $3 \mathrm{~g} / \mathrm{ha}$, results showed weak efficacies that did not exceed $48.8 \%$ of $R$. segetum dry biomass reduction. Suresh Kumar $\&$ al. (2011) reported that Tank mixture of clodinafop $60 \mathrm{~g} / \mathrm{ha}+$ metsulfuron methyl $4 \mathrm{~g} / \mathrm{ha}$ and clodinafop 120 $\mathrm{g} / \mathrm{ha}+$ metsulfuron methyl $8 \mathrm{~g} / \mathrm{ha}$ with and without surfactant $0.2 \%$ provided excellent control of weeds in wheat crop.

Table 3: Effect of treatments on R. segetum dry biomass reduction (\%)

\begin{tabular}{lll}
\hline Treatments & $\begin{array}{l}R . \quad \text { segetum density } \\
\text { reduction }(\%)\end{array}$ \\
\hline $\begin{array}{l}\text { Metsulfuron Methyl at } 3 \\
\text { g/ha }\end{array}$ & $48.8^{\mathrm{a}}$ \\
\hline $\begin{array}{l}\text { Metsulfuron Methyl at } 6 \\
\text { g/ha }\end{array}$ & $92.7^{\mathrm{b}}$ \\
\hline $\begin{array}{l}\text { Metsulfuron Methyl at } 9 \\
\text { g/ha }\end{array}$ & $94.5^{\mathrm{b}}$ \\
\hline$P \alpha=0.05$ & $<0.001$ \\
\hline
\end{tabular}

$\overline{\text { Significant differences within the same column and means }}$ followed by the same letter do not differ at $P=0.05$ according to Tukey's test 


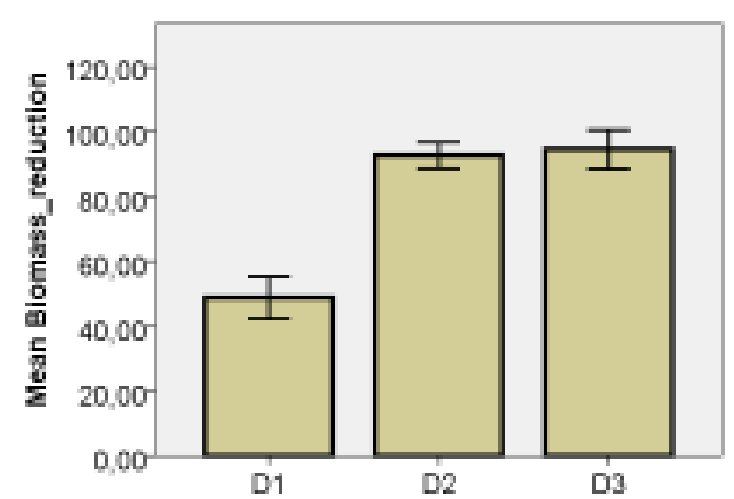

D1 : Metsulfuron Methyl at $6 \mathrm{~g} / \mathrm{ha}$; D2 : Metsulfuron Methyl at $6 \mathrm{~g} / \mathrm{ha}$; D3 : Metsulfuron Methyl at $9 \mathrm{~g} / \mathrm{ha}$ Error Bars: $95 \%$ CI

Fig.2: Effect of treatments on R. segetum dry biomass reduction (\%)

\section{CONCLUSION}

This study has shown that the herbicide Metsulfuron Methyl at $6 \mathrm{~g} / \mathrm{ha}$ and $9 \mathrm{~g} / \mathrm{ha}$ gave the best control of $\mathrm{F}$. parviflora. Metsulfuron Methyl at $3 \mathrm{~g} / \mathrm{ha}$ showed weak to medium control of F. parviflora. Thus, Metsulfuron Methyl at $6 \mathrm{~g} / \mathrm{ha}$ can be recommended to farmers in Ouazzane region when $R$. segetum infestation is dominant. This study should be completed with the assessment of Metsulfuron Methyl residues in soils and its phytotoxicity to crops grown in rotations.

\section{ACKNOWLEDGMENTS}

The authors are grateful to all technicians of ONCA Ouazzan for providing necessary facilities for conducting this research work.

\section{REFERENCES}

[1] Bouhache M. (2017). Chemical weed control in autumn sown cereals. Agriculture du Maghreb Num. 25: 57-62. French.

[2] Bouhache M. (2017). Strengths and weaknesses of herbicides used on cereals in Morocco. Agriculture du Maghreb Num. 100: 9-19. French

[3] Boutahar K. (1994). Impact of harvest date and presence of weeds on grain losses at harvest operation. Al Awamia Num. 85: 25-32. French.

[4] Ezzahiri B., Bouhache M., Mihi M. (2017). Phytosanitary index of Morocco. AMPP Maroc Editions. French.

[5] IBM SPSS Statistics for Windows, Version 21.0. (2012). Armonk, NY: IBM Corp.

[6] Suresh Kumar, N.N. Angiras \& S.S. Rana. (2001). Bioefficacy of clodinafop-propargyl + metsulfuron methyl against complex weed flora in wheat. Indian Journal of Weed Science 43 (3\&4) : 195-198

[7] Taleb A. (1996). Weed flora of Morocco, Characterization and economic importance. Bulletin de transfert de technologie en agriculture Rabat Maroc, Num. 18. French.
[8] Tanji A. (2005). Weeds of wheat and barley in Morocco. INRA Editions, Rabat Morocco. French

[9] Zimadahl RL , El Brahli A. (1992). Losses caused by weeds on cereals in the semi-arid zone of western Morocco. Al Awamia Num. 75: 53-62. French 